\title{
First Record of Brachiopod Species in Myanmar
}

\author{
Ye Yint Aung1, Chit Sein² \\ ${ }^{1}$ Department of Geology, Taungoo University, Taungoo, Myanmar \\ ${ }^{2}$ Yangon University of Distance Education, Yangon, Myanmar \\ Email: yeyintaunggeol@gmail.com,chitsein@gmail.com
}

How to cite this paper: Aung, Y.Y. and Sein, C. (2022) First Record of Brachiopod Species in Myanmar. Open Journal of Geology, 12, 80-90.

https://doi.org/10.4236/ojg.2022.121004

Received: December 8, 2021

Accepted: January 17, 2022

Published: January 20, 2022

Copyright $\odot 2022$ by author(s) and Scientific Research Publishing Inc. This work is licensed under the Creative Commons Attribution International License (CC BY 4.0).

http://creativecommons.org/licenses/by/4.0/ (c) (i) Open Access

\begin{abstract}
The Paleozoic rocks are well exposed in the Taungnyo area and the main purpose of classification is taxonomic status of the invertebrate fossils and describing the systematic paleontology of brachiopod fossils from Taungnyo Formation. Mainly distributed clastic sedimentary rocks of Taungnyo Formation (Early Carboniferous) and carbonate rocks of Moulmein Limestone Group (Permian to Middle Triassic) are well exposed in the Taungnyo area. In this study, mainly, a total of five species are recognized in the clastic sediments of Taungnyo Formation. Most brachiopods are generally found abundant and well preserved in the mudstone unit. Among them, most of the taxa have not been recorded previously. The brachiopods include: Fimbrispirifer venustus, Ovetensispirifer ovetensium, Aullacella sp., Kayserellae emanuelensis, and Chonopectus sp. All of the species are first recorded in Myanmar.
\end{abstract}

\section{Keywords}

Brachiopod, Taungnyo Formation, Systematic Paleontology, Myanmar

\section{Introduction}

Carboniferous to Lower Permian rock units are widely distributed in the southeastern part of the Taungnyo range. A few previous workers were carried out in this area for geological, sedimentological purposes, and the brachiopod fossils have been found from the rocks of Taungnyo Formation (cited previous authors, e.g. Kyaw Min, 1997; Moe Zat, 2006; Nay Zar Zar Linn Aung, 2006; Day Wa Aung, 2014) [1] [2] [3] [4]. However, the systematic paleontological analysis of Taungnyo Formation is still lacking in this area. The present study aims the first attempt to identify and study invertebrate fossils in Taungnyo Formation from the interior to discuss their systematic paleontology of brachiopods in the Taungnyo range. 


\section{Location, Materials, and Methods}

The study area is located in the Taungnyo area, about $4.8 \mathrm{~km}$ from southsoutheast of Mawlamyine Township, Mon State (Figure 1). The detailed fieldwork was carried out to record different rock units and their lithologic characters. The stratigraphic sections were measured by Jacob's staff methods, on different desired localities and fossils were collected systematically during the stratigraphic section measurements. All the brachiopods species in the Taungnyo Formation are arranged systematically described taxonomically. All types of species were selected and their images were photographed.

\section{Regional Geologic Setting}

The study area is positioned in the southeastern part of Mawlamyine and Taungnyo range, Shan Tanintharyi Belt [5]. The region corresponding to present day Taungnyo range is located in the central Shan Tanintharyi Belt between the latitudes $16^{\circ}$ and $17^{\circ}$. The study area comprises clastic sedimentary rocks of Taungnyo Formation which has been correlated with the Lebyin Group of southern Shan State and Mergui Group of Tanintharyi Region. Regionally, the Taungnyo range is primarily covered by the Paleozoic strata with the brachiopods and other marine invertebrate fauna in this area. Nearly N-S trending features of the range are mainly reflected by the orogenic movements. The study

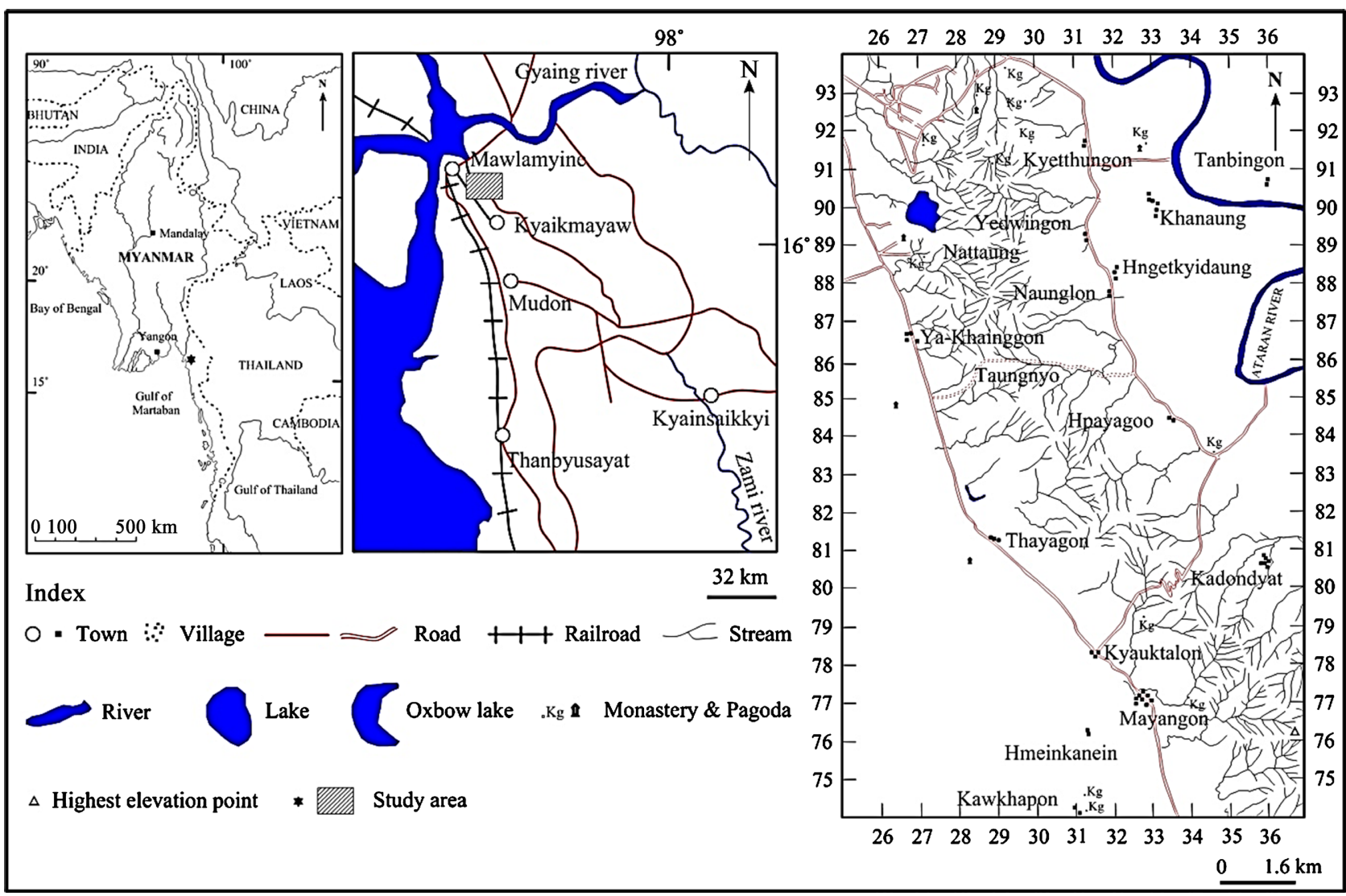

Figure 1. Location map of the study area. 
area consists of clastic sedimentary rocks and limestone that occurred as belts trending NW-SE direction. The regional geological map of the study area is shown in Figure 2.

The Paleozoic rock units are well exposed in the Taungnyo range. The Lower Paleozoic rock units are Mogok Group (Paleozoic and partly Jurassic). Paleozoic to Mesozoic units are Taungnyo Group (Carboniferous to Lower Permian), Plateau Limestone Group (Middle Permian to Middle Triassic), Bawgyo Group (Triassic). A Cenozoic rock unit is Irrawaddy Formation (Upper Miocene to Pliocene).

A sequence of argillite, quartzite, and sandstone several thousands of meters thick were grouped by Leicester (Pescoe, 1930) [7] as the Taungnyo Series (after the Taungnyo range south of Moulmein). In the Zwekabin range south of $\mathrm{Pa}$-an Township, an Upper Carboniferous fauna was recovered by Brunnschweiler (1970) [8] from the calcareous sandstone of the Taungnyo Series. The fossils assemblage includes gastropods, brachiopods, bryozoans, corals, and ostracods. Kyaw Min (1997) [1] carried out research work and he described the Geology of Taungnyo area (Mawlamyine, Mudon, and Kyaikmaraw Twonships) which is the north part of the present research work and he found that the Carboniferous
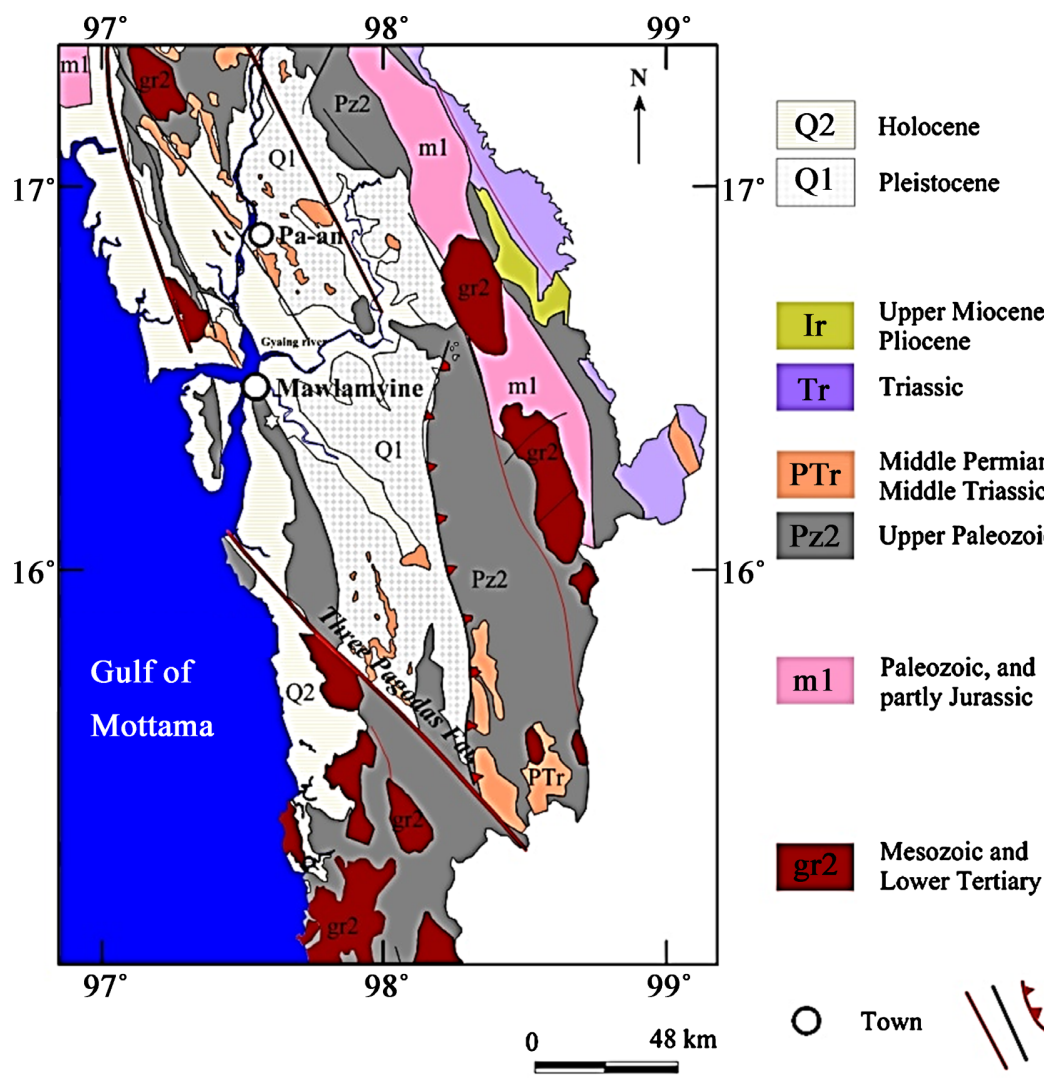

\section{Explanation}

Younger Alluvium

Older Alluvium, Gem Gravels of Mogok; Uyu Bolder Conglomerates; Terraces of Ayeyarwady and Chindwin Rivers; Uplifted marine terraces along the Rakhine Coast; terra rossa of Shan State, Laterite

Ir Upper Miocene - Irrawaddy Formation, and its equivalents; Oil shales Pliocene of Kayin State

$\mathrm{Tr}$ Triassic Thanbaya Formation; Bawgyo Group; Kamawkala Limestone; and their equivalents

Middle Permian - Plateau Limestone Group; Moulmein Limestone; and Middle Triassic their equivalents; Yinyaw Beds, and its equivalents

Upper Paleozoic Taungnyo Formation and Lebyin Group (Carboniferous to Lower Permian), and their equivalents; lower part of Mergui Group (possibly Silurian to Carboniferous) Zebingyi Formation, and its equivalents

m1 Paleozoic, and Metamorphosed units of mainly Lower Paleozoic rocks Mogok Metamorphic Belt and its extensions: Mogok Group (Pz); Eastern Kachin metamorphics (including Up. PE); Kyaukse metamorphics (Pz and Jurassic); Yinmabin metamorphics (Pz); possibly Mawchi Series; and their equivalents

Mesozoic and Granitoids - granite, granodiorite, diorite, and non-basic Lower Tertiary intrusives; locally transformed into granite gneiss and metadiorite

Town

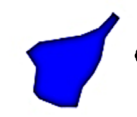
Gulf and River Geological boundary \& Study area

Figure 2. Regional Geological map of the study area (cited from a geological map of Myanmar, Soe Thura Tun, Maung Thein, Nyunt Htay and Kyaing Sein, 2014) [6]. 
fauna such as brachiopods, gastropods, bryozoans, and crinoids in the Taungnyo Formation. Brachiopods are the most abundant group. This formation consists of clastic sedimentary rocks such as sandstone, shale, slate, siltstone, argillite, and mudstone. Sandstone is mostly quartzose sandstone, arenite, pebbly greywacke, and quartzwacke. Shale is pink, purple, reddish, and yellowish in color.

The Taungnyo Formation is overlain by Moulmein limestone (Permian age) with an unconformity. The existence of an unconformity is seen in Zwekabin range, which is located in the north of the study area. Taungnyo Formation is a general trend of NNW-SSE direction and has been subdivided into three major lithologic units; $\mathrm{C}_{1} \mathrm{t}^{1}$ unit, $\mathrm{C}_{1} \mathrm{t}^{2}$ unit, and $\mathrm{C}_{1} \mathrm{t}^{3}$ unit. Brachiopods were found in fossiliferous mudstone of $\mathrm{C}_{1} \mathrm{t}^{2}$ unit.

Moulmein Limestone Group is exposed as isolated hills on the alluvial plains at the eastern and western part of the Taungnyo range. Moulmein Limestone Group is chiefly composed of carbonate sedimentary rocks with a general trend of NW-SE direction. Moulmein Limestone Group is Permian age and can be correlated with Plateau Limestone Group of southern Shan State, due to lithological and biological characters.

\section{Systematic Paleontology}

The classification of brachiopod follows by Treatise on Invertebrate Paleontolo$g y$ (Moore R. C., 1965) [9] and other international papers.

$\begin{array}{ll}\text { Phylum } & \text { BRACHIOPODA (Dumeril, 1806) [10] } \\ \text { Subphylum } & \text { RHYNCHONELLIFORMEA (Williams, Carlson, Brunton } \\ & \text { Holmer and Popov, 1996) [11] } \\ \text { Class } & \text { RHYNCHONELLATA (Williams, Carlson, Brunton Holmer } \\ & \text { and Popov, 1996) } \\ \text { Order } & \text { SPIRIFERINIDA (Ivanova, 1972) [12] } \\ \text { Subordrer } & \text { DELTHYRIDINA (Ivanova, 1972) } \\ \text { Superfamily } & \text { DELTHYRIDOIDEA (Phillips, 1841) [13] } \\ \text { Family } & \text { FIMBRISPIRIFERIDAE (Pitrat, 1965) [14] } \\ \text { Genus } & \text { Fimbrispirifer (Cooper, 1942) [15] } \\ \text { Fimbrispirifer venustus (Hall, 1860) [16] [17] (Figure 3) }\end{array}$

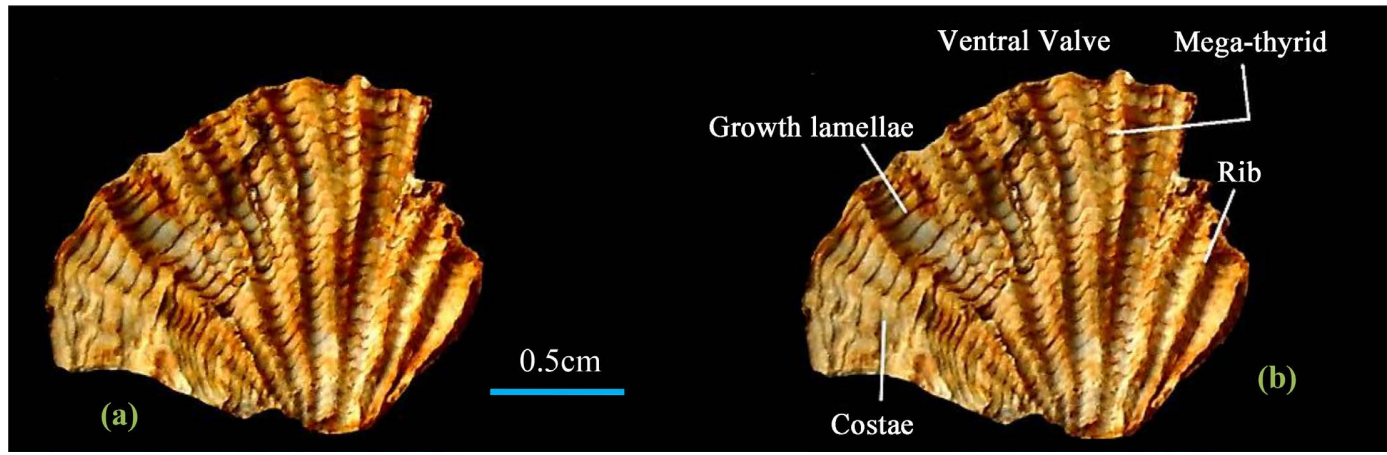

Figure 3. Fimbrispirifer venustus from Taungnyo Fm. in Myanmar. (a) Interior view of ventral valve in internal mould, (b) terminology of the fossil specimen (TN-6). 
Material-The specimen is collected from the light grey to dark grey color mudstone of Taungnyo Formation, near the west of Shwekyatkya monastery.

Locality-Near the west of Shwekyatkya Monastery, south-east of Pokukku monastery.

Description-Form and size; shells medium-sized with bifurcating and trifurcating ribs on flanks. Outline semi-elliptic to sub-triangular. Exterior of ventral valve; interarea high, catacline to apsacline, and curved in the upper part. Delthyrium open. Deltidial lamella and deltidium lacking. Sulcus broad and rounded in cross section. Exterior of dorsal valve; interarea low and ancline. Folds are moderately high. Coarse ornamentation; ribs unequally bifurcating and trifurcating on the posterior half of the flanks at the same growth stage. Each rib multiplies only once. Sulcus with a median furrow. Ribs are bifurcating to median form the sulcus bordering ribs always at the same growth stage. Ribs on hold bifurcating from the most lateral rib to median or from the first pair of a rib to lateral. Ribs on the fold and in the sulcus are of the same size as ribs on the flanks. All ribs are fine, separated by fine furrows. Ribs and furrows rounded to angular in cross-section.

Age-Middle Devonian to Carboniferous

Family OVENSISPIRIFERIDAE (Pitrat, 1965)

Genus Ovensispirifer nov. (Carls, 1986) [18]

Ovetensispirifer ovetensium (Carls, 1986) (Figure 4)

Material-The specimen is collected from the light grey to dark grey color mudstone of Taungnyo Formation, near the west of Shwekyatkya monastery.

Locality-Near the west of Shwekyatkya Monastery, south-east of Pokukku monastery.

Description-Shells medium-sized, megathyrid without mucronations, and sub-elliptical in outline; equibiconvex to dorsibiconvex in longitudinal section. The exterior of ventral valve; ventral interarea moderately high, apsacline, and curved. Delthyrium open, deltidial lamellae clearly developed, deltidium lacking.

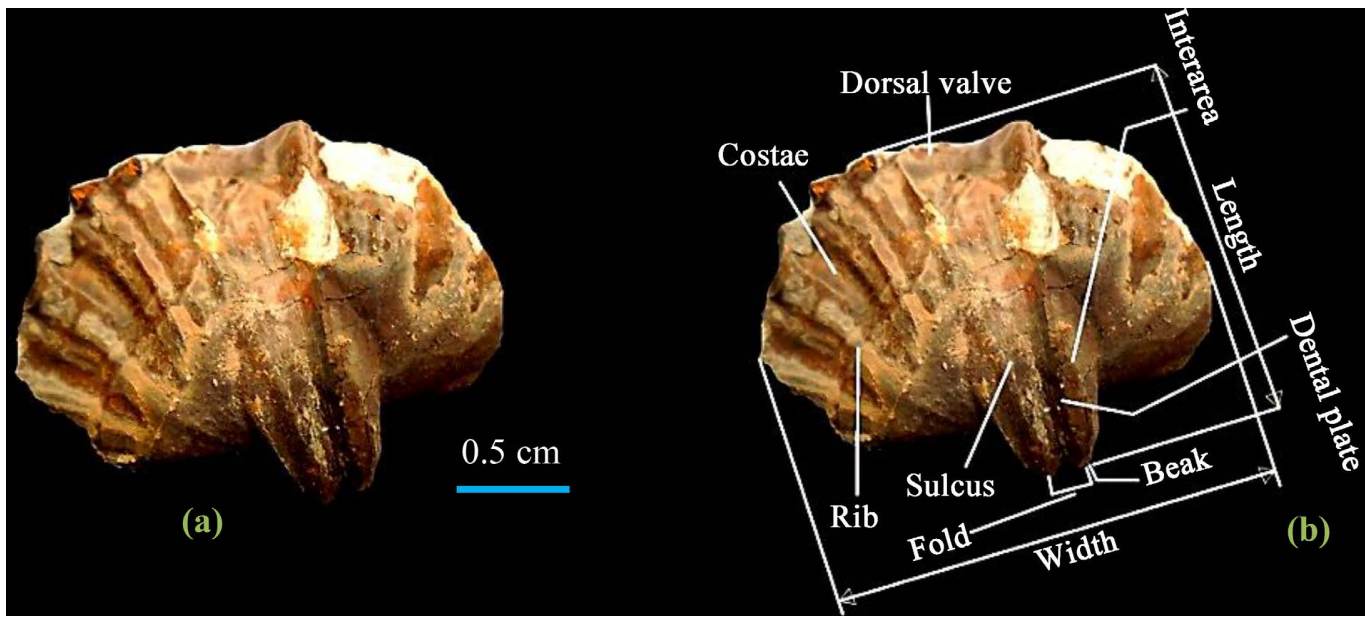

Figure 4. Ovetensispirifer ovetensium from Taungnyo Fm. in Myanmar. (a) Exterior view of dorsal valve complete specimen, (b) terminology of the fossil specimen (TN-50). 
Exterior of dorsal valve; dorsal interarea low, anacline and curved. Notothyrium is not recognizable. Coarse ornamentation; ventral and dorsal valves are covered by numerous fine ribs with furrows of the same size. Ribs are angular to rounded in cross-section and do not bifurcate on flanks, furrows are angular in cross-section. Lateral ribs in the sulcus and on fold bifurcate once in the adult stage. Usually 3 ribs in the sulcus and 4 ribs on the fold, in geronitc stage 5 ribs in the sulcus and 6 ribs on the fold. Growth lamellae are rarely developed at the anterior margin.

Discussion-Ovetensispirifer ovetensium is smaller than $O$. novascotianus has 2 ribs less in the sulcus, and 2 impressions of ribs on each side of the internal mould of the ventral muscle field whereas $O$. novascotianus has 4 to 5 impression of ribs on the internal mould of the ventral muscle field.

Age-Middle Devonian to Carboniferous

Family RHIPIDOMELLIDAE (Schuchert, 1913) [19]

Subfamily RHIPIDOMELLIDAE (Schuchert, 1913) [19]

Genus Aulacella (Schuchert \& Cooper, 1931) [20]

Aulacella sp. (Schuchert \& Cooper, 1931) [20] (Figure 5)

Material-The specimen is collected from the light grey to dark grey color mudstone of Taungnyo Formation, near the west of Shwekyatkya monastery.

Locality-Near the west of Shwekyatkya Monastery, south-east of Pokukku monastery.

Description-Shells medium-sized, wider than long (width/length ratio; 1.09 1.36), dorsibiconvex, sub-quadrangular in outline; hinge line shorter than greatest width (hinge line width/width; 0.34 - 0.56); maximum width at about midlength or slightly anteriorly; anterior commissure rectimarginate to uniplicate, rarely paraplicate. Ventral valve regularly convex in lateral profile, semi-elliptical in posterior view; sulcus either absent or shallow, with bottom flattened to round. Dorsal valve regularly and moderately inflated in lateral profile; highest at about mid valve or more anteriorly but not at the front; median depression in some specimens developed in its posterior part but reaching rarely the front;

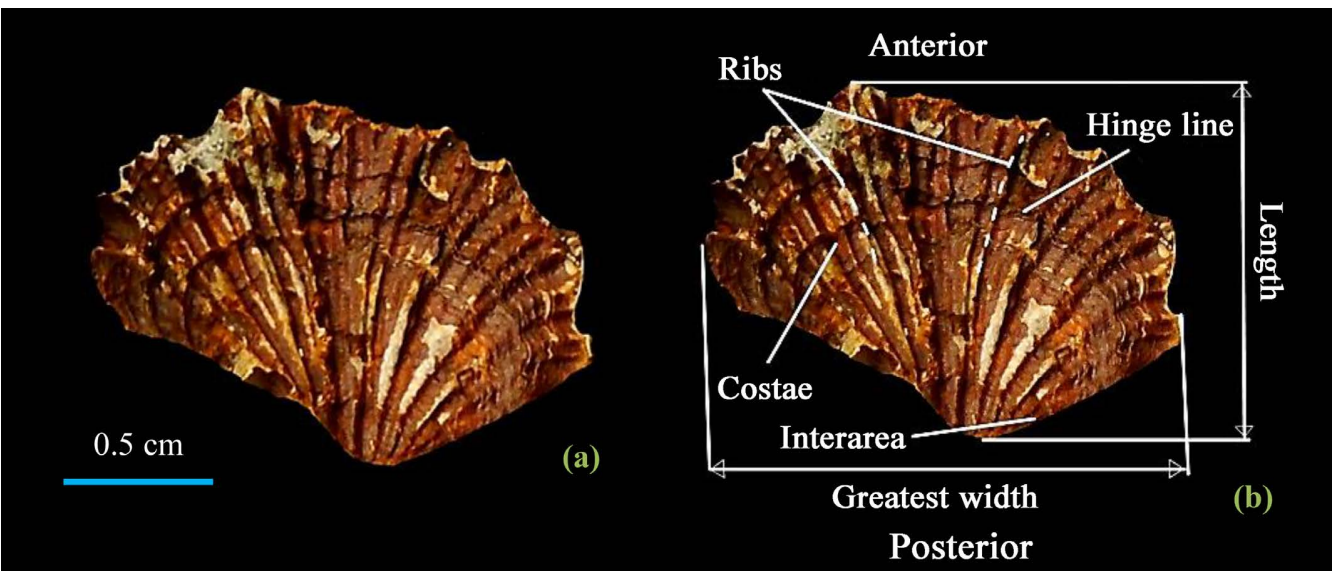

Figure 5. Aullacella sp. from the locality of Taungnyo range, Taungnyo Fm. in Myanmar. (a) Exterior view of dorsal valve in internal mould, (b) terminology of the fossil specimen (TN-5). 
interarea orthocline, flat, generally less developed than the ventral one.

Discussion-Aulacella sp. was long misidentified as A. arcuate (Phillips, 1841) [13], a poorly known species from the Middle Devonian of Hope's Nose, Torquay in south Devon (England) but, however, it differs from the latter by a greater size and a narrower outline. Aulacella sp. has a less delimited and less elongated ventral muscle field than that of $A$. interlineate (Sowerby, 1840) [21]. Aulacella sp. is never as inflated as $A$. eifliensis (Schnur, 1853) [22]. Moreover, its outline is more developed in width and its ornamentation is coarser. Aulacella sp. differs from Rhipidomella manticula (Stainbrook, 1947) [23] by its greater size and its equibiconvex to dorsibiconvex profile. This species has been assigned to Aulacella by Cooper \& Dutro (1982) [24]. Aulacella sp. is distinguished from $A$. xinanensis (Chen, 1978) [25] by its larger size, a more flattened profile and its wider outline. Aulacells sp. is larger than A. elliptica (Cooper \& Dutro, 1982) [24] form which it also differs in its coarser ornamentation.

Age-Late Devonian to Carboniferous

Family KAYSERELLIDAE (Schnur, 1854) [22]

Genus Kayserella (Hall \& Clarke, 1892) [26], emended (Cooper, 1955) [27] [28] [29]

Kayserella emanuelensis (Figure 6)

Material-The specimen is collected from the light grey to dark grey color mudstone of Taungnyo Formation, near the west of Shwekyatkya monastery.

Locality-Near the west of Shwekyatkya Monastery, south-east of Pokukku monastery.

Description-Outline sub-circular, profile biconvex, ventral valve with greater depth. Convexity of both valves greatest posteriorly, least along anterior borders which are almost flat. Hinge line two-thirds shell width, measured at midlength. Cardinal margins are obtuse, rounded in some specimens but usually angular. The dorsal valve is shallowly and broadly sulcate, anterior commissure broadly sulcate to nearly straight. The ventral valve of the interarea is moderately long, apsacline umbo straight to nearly erect. The dorsal valve of interarea is half-length

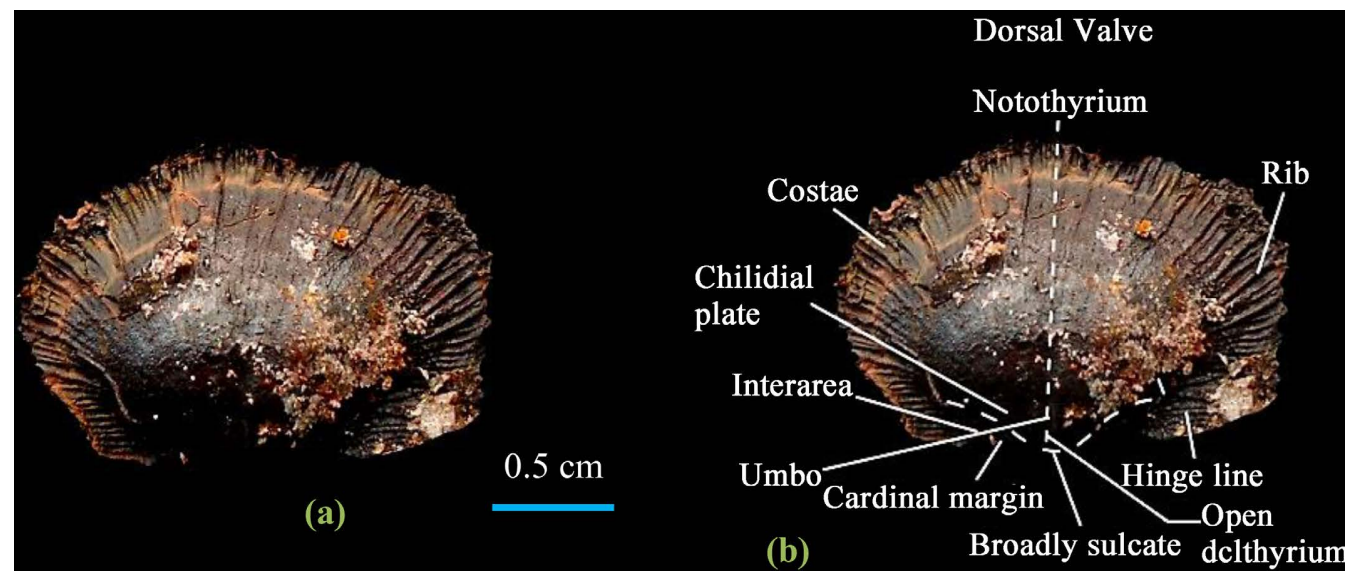

Figure 6. Kayserella emanuelensis from Taungnyo Fm. in Myanmar. (a) Exterior view of dorsal valve, complete and well preserved shell, (b) Terminology of the fossil specimen (TN-48). 
of ventral interarea, anacline. Delthyrium open, wide with thickened margins. Notothyrium is partly closed by cardinal process and narrow chilidial plates.

Discussion-As a result of Cooper's (1955) revision, Kayserella has become a finely drawn genus, narrowly separable from similar orthoidgenera, such as $\mathrm{My}$ strophora (Kayser, 1871) [30] and Monelasmina (Cooper, 1955). In fact, these genera, as now defined, can only be distinguished with suitable well preserved material. Fortunately the new species is sufficiently well preserved for a detailed examination, which shows that the species, with its long high median septum dividing the shell into two halves, and inner socket plates supported by a long narrow cruralium, is a member of Kayserella, K.emanuelensis differs specifically form the type species, $K$. lepida (Schnur), in being more weakly sulcate and in having a more highly longer crurlium. K. emanuelensis also differs from the basal Middle Devonian species $K$. americans (Cooper, 1955), with which it agrees in external shape, in having a longer cruralium. Kayserella? Karaghensis (Reed, 1922) [31] (pp. 35, 36, pl.6, figs. 14, 15) from the Upper Devonian of Koragh near Reshun Chitral, is very similar externally to $K$. emanuelensis. As the interior of Reed's species is unknown it is of course possible that this external similarity is not maintained internally.

Age-Late Devonian to Carboniferous

Super Family STROPHALOSIOIDEA (Schuchert, 1913) [19]

Genus Chonopectus (Hall \& Clarke, 1892) [26]

Chonopectus sp. (Hall \& Clarke, 1892) [26] (Figure 7)

Material-The specimen is collected from the light grey to dark grey color mudstone of Taungnyo Formation, near the west of Shwekyatkya monastery.

Locality-Near the west of Shwekyatkya Monastery, south-east of Pokukku monastery.

Description-Shell concavo-convex, sub-elliptical or sub-circular in outline, usually wider than long, the hinge-line usually a little shorter than the greatest width of the shell, the hinge extremities sub-rectangular or a little rounded. The dimensions of two individuals are; length $26 \mathrm{~cm}$ and width $40.8 \mathrm{~cm}$ and $7.5 \mathrm{~cm}$ thickness. Pedicle valve most convex near the middle, becoming moderately

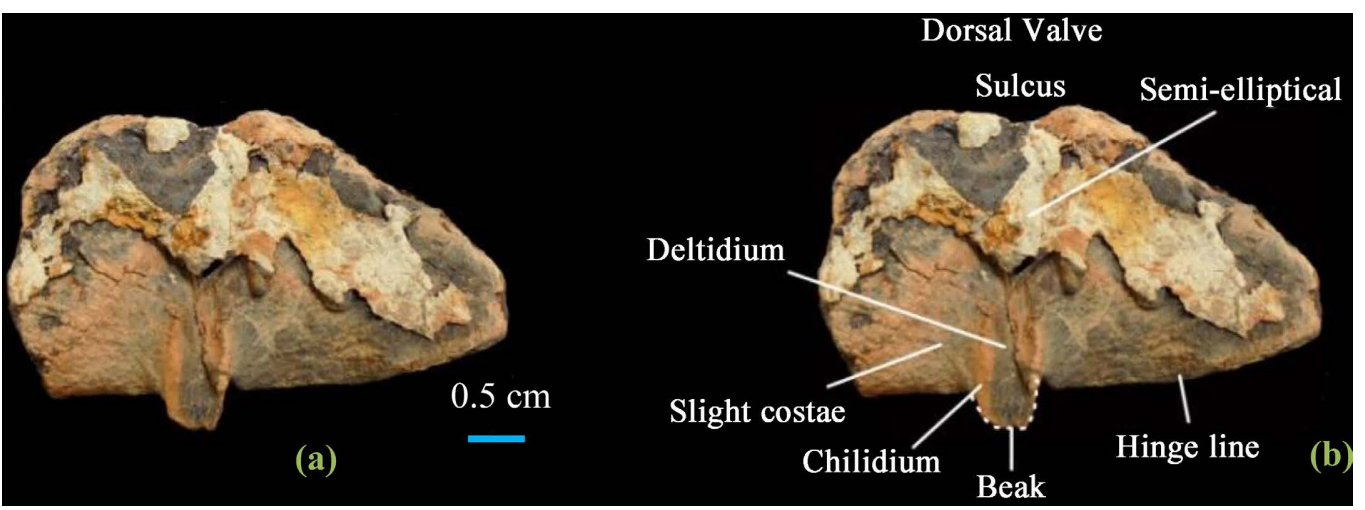

Figure 7. Chonopectus sp. from Taungnyo Formation in Myanmar. (a) Exterior view of dorsal valve, well preserved and exfoliated shell, (b) terminology of the fossil specimen (TN-49). 
compressed towards the cardinal extremities, with no medial sinus or medial flattening of the valve; the umbonal region usually a little flattened, the beak scarcely protuberant beyond the cardinal margin; the cardinal margin sharply defined, bearing about four, slender, obliquely curved spines. Brachial valve moderately concave with the greatest concavity near the middle, the surface becoming flattened towards the cardinal extremities; at the beak or initial point of the valve, close to the cardinal margin, is a small, round, node-like protuberance. The cardinal area, cardinal process, and internal features of the shell not observed.

Discussion-This species is by far the most abundant in the sandstone. Not a fragment of the rock in the fossiliferous layers can be broken without exposing one or more specimens of this species and the number of individuals' present is many times that of other species in the fauna. As they occur in the sandstone, the surface markings are usually obliterated to a very great extent so that they appear to be nearly smooth but the concentric lines or wrinkles of growth may usually be observed near the hinge-line, and also the curved diagonal lines.

Age-Late Devonian

\section{Conclusions}

1) The present paper focus on the analysis of brachiopod is described by five species in this work. These species have not been recorded from Myanmar but were previously named in the world.

2) The brachiopod fauna was able to be rich in the widespread in the mudstone unit of Taungnyo range. Brachiopods, especially, Spirifer, Aulacella, Kayserellae and Chonopectus are the most common element in the Taungnyo Formation.

3) New discovery of brachiopods fossils was very significant for the geological age of Taungnyo Formation. The geological age of Taungnyo Formation is Carboniferous age but the research area is found Devonian age of Brachiopods fauna.

4) According to the discovery of brachiopod fauna, Taungnyo Formation is possible until the Middle Devonian-Carboniferous age and this formation should be made amendments to the geological age.

\section{Acknowledgements}

The authors are grateful to the Department of Higher Education, Ministry of Education, for encouragement and permission this research programmed to come out the present work. Special thanks are due to anonymous reviewers for their helps to improve of the paper. We are extremely grateful to Dr. Day Wa Aung, Professor and Head of the De-partment of Geology, Yangon University for his enthusiastic help. Finally, we are also indebted to Dr. Lin Thu Aung (Researcher, Earth Observatory of Singapore) and Open Journal of Geology (OJG) for critical reading and valuable suggestions of this work. 


\section{Conflicts of Interest}

The authors declare no conflicts of interest regarding the publication of this paper.

\section{References}

[1] Kyaw, M. (1997) Geology of Taungnyo Area, Mawlamyine, Mudon and Kyaikmayaw Townships. M.Sc. Thesis, University of Mawlamyine, Myanmar.

[2] Moe, Z. (2006) Geological and Petrological Study on Paleozoic Rocks of Mawlamyine and Its Environs. M.Sc. Thesis, University of Mawlamyine, Myanmar.

[3] Nay, Z.Z.L.A. (2006) Geological Study on Paleozoic Rocks of the Eastern Mudon Area, Mudon Township, Mon State. M.Sc. Thesis, University of Mawlamyine, Myanmar.

[4] Day, W.A. (2014) Sedimentology of Taungnyo Formation in Mawlamyine Area, Mon State. Proceedings of the 13th Regional Congress on Geology, Mineral and Energy Resources of Southeast Asia, Yangon, 10-11 March 2014, 43.

[5] Bender, F. (1983) Geology of Burma. Gebruder Borntraeger, Berlin, Stutgart, 230.

[6] Soe, T.T., Maung, T., Nyunt, H. and Kyaing, S. (2014) Geological Map of Myanmar, 2014. Scale 1:2,250,000. Myanmar Geosciences Society.

[7] Pescoe (1930) General Report of the Geological Survey of India for the Year 1929. Records of the Geological Survey of India, 63, 1-154.

[8] Brunnschweiller, R.O. (1970) Contribution to the Geology of Burma: New Formations and Structures in the Northern Shan State and in Karen State. Unpublished Report of the Burma Geological Department. https://doi.org/10.1080/00167617008728724 https://www.tandfonline.com/doi/abs/10.1080/00167617008728724

[9] Moore, R.C., Teichert, C. and Robison, R.A., Eds. (1965) Treatise on Invertebrate Paleontology. Part H: Brachiopods, I. University Press of Kansas, Lawrence, Kansas, $521 \mathrm{p}$.

[10] Dumeril, A.M.C. (1806) Zoologie analytique ou method naturelle de classification des animaux. Xxiv +344 pp. Allais, Paris.

https://books.google.com/books?hl=en\&lr=\&id=kKM-AAAAcAAJ\&oi=fnd\&pg=PA1 53\&dq=\%5B10\%5D\%09Dumeril,+A.+M.+C.+(1806)+Zoologie+analytique + ou + meth od+naturelle+de+classification+des+ani-maux.+Xxiv+\%2B+344+pp.+Allais,+Paris

[11] Williams, A., Carlson, S.J., Brunton, C.H.C., Holmer, L.E. and Popov, L. (1996) A Supra-Ordinal Classification of the Brachiopoda. Proceedings of the Royal Society B: Biological Science, 351, 1171-1193. https://doi.org/10.1098/rstb.1996.0101 https://royalsocietypublishing.org/doi/abs/10.1098/rstb.1996.0101

[12] Ivanova, E.A. (1972) Main Features of Spiriferid Evolution (Brachiopoda). Paleontologiceskii zurnal, 1972, 28-42. [In Russian]

[13] Phllips, J. (1841) Figures and Descriptions of the Paleozoic Fossils of Cornwall, Devon and West Somerset. Longman, Brown, Green \& Longmans, London, 52-92. http://www.envihub.org.uk/resources/phillips-j-1841

[14] Pitrat, C.W. (1965) Spiriferidina. In: Moore, R.C., Teichert, C. and Robison, R.A., Eds., Treatise on Invertebrate Paleontology, Vol. 2, Part H, Geological Society of America and University of Kansas Press, Lawrence, 667-728.

[15] Cooper, G.A. (1942) New Genera of North American Brachiopods. Washington Academy of Sciences Journal, 32, 228-235. 
https://www.jstor.org/stable/24531261

[16] Hall, J. (1860) Observations on Brachiopoda. Observations on Brachiopoda: New York State Cabinet of Natural History, 13th Annual Report, 65-71.

[17] Hall, J. (1860) Descriptions of New Species of Fossils, from the Hamilton Group of Western New York, with Notices of Others from the Same Horizon in Lowa and Indiana. In: New York State Cabinet of Natural History, 13th Annual Report, Albany, 76-94.

[18] Carls, P. (1986) Howellella (Hysterohowellella) Knetschi (Brachiopoda, Spiriferacea) aus dem tiefen unter Gedinnium Keltiberiens. Senckenbergiana Lethaea, 65, 297-326, 2pl.

[19] Schuchert, C. (1913) Class Brachiopoda. In: The Lower Devonian Deposits of Maryland, Maryland Geological Survey, Baltimore, 290-449, Plates 53-74.

[20] Schuchert, C. and Cooper, G.A. (1931) Synopsis of the Brachiopod Genera of the Suborders Orthoidea and Pentameroidea with Noteson the Telotremata. American Journal of Science, Series, 5, 241-251.

[21] Sowerby, J. (1840) Explanation of the Plates and Wood-Cuts (Organic Remains Engraved and Described by Mr J. de C. Sowerby). Transactions of the Geological Society, 5, 52-67.

[22] Schnur, J. (1853-1854) Zusamenstellung und Beschreibung Sammtlicher im Uebergangsgebirge der Eifel vorkommenden Brachiopoden, nebst, Abbildungen derselben, Palaeontographica, 3, 169-253.

[23] Strainbrook, M.A. (1947) Brachiopoda of the Percha Shale of New Mexico and Arizona. Journal of Paleontology, 21, 297-328. https://www.semanticscholar.org

[24] Cooper, G.A. and Dutro, J.T. (1982) Devonian Brachiopods of New Mexico. Bulletin of American Paleontological Association, 82-83, 1-215.

[25] Chen, X.-Q. (1978) The Relationship between the Brachiopod Genera Yingtangella Bai \& Ying, 1978 and Rhipidothyris Cooper \& Williams, 1935. Alcheringa, 32, 191-198.

[26] Hall, J. and Clarke, J.M. (1892) An Introduction to the Study of Genera of Paleozoic Brachiopods. Vol. 8, Charles Van Benthuysen \& Sons, Albany, 367 p., 20pl.

[27] Cooper, G.A. (1955) New Genera of Middle Paleozoic Brachiopods. Journal of Paleontology, 29, 45-63, Plates 11-14.

[28] Cooper, G.A. (1955) New Brachiopods from Cuba. Journal of Paleontology, 29, 64-70, Plate 15.

[29] Cooper, G.A. (1955) New Cretaceous Brachiopoda from Arizona. Smithsonian Miscellaneous Collections, 131, 1-18, 4 Plates.

[30] Kayser, E. (1871) Die Brachiopoden des Mittel and Ober-Devon der Eefel. Zeitschrift der Deutschen Geologischen Gesellschaft, 23, 491-647, pl. 9-14.

[31] Reed, F.R.C. (1922) Devonian Fossils from Chitral and the Pamirs. Palaeontologia Indica, 6, 1-134, 16 pis.

\section{Abbreviation}

TN Taungnyo (name of the fossil specimen number)

Fm. Formation (name of rock unit in the study area) 